\title{
DETERMINATION OF PRODUCT DIVERSITY IN CHINA'S EXPORT SECTORS IN 2001-2017 THROUGH CLUSTERING ANALYSIS ${ }^{1}$
}

\author{
DOI: 10.17261/Pressacademia.2020.1316 \\ JBEF- V.9-ISS.4-2020(7)-p.356-372
}

\author{
Nevzat Balikcioglu ${ }^{1}$, Irmak Turkkahraman ${ }^{2}$ \\ ${ }^{1}$ Sivas Cumhuriyet University, Faculty of Economics and Administrative Sciences, Department of Economics, Sivas, Turkey, \\ balikcioglu@cumhuriyet.edu.tr ORCID 0000-0002-8642-9013 \\ ${ }^{2}$ Sivas Cumhuriyet University, Institute of Social Sciences, Sivas, Turkey. \\ irmakturkkahraman@gmail.com, ORCID 0000-0001-6528-652X
}

Date Received: September 16, 2020

Date Accepted: December 4, 2020

To cite this document

Balikcioglu, N., Turkkahraman, I., (2020). Determination of product diversity in China's export sectors in 2001-2017 through clustering analysis. Journal of Business, Economics and Finance (JBEF), V.9(4), p.356-372.

Permanent link to this document: http://doi.org/10.17261/Pressacademia.2020.1316

Copyright: Published by PressAcademia and limited licensed re-use rights only.

\begin{abstract}
Purpose- It is to evaluate the export-oriented general economic structure of China, which alone meets $20 \%$ of world exports today, and to reveal the changes and cluster differences in the export products group of China before and after its membership to the WTO.

Methodology- It is to reveal and interpret the change in China's exports before and after becoming a member of the WTO by sectoral cluster analysis method.

Findings- When China's total export from 1992 to 2017 and the export changes in 25 different sectors are examined, it is observed that there is a significant increase in all sectors.

Conclusion- Statistically significant differences were found for each sector before and after China's WTO membership. This shows that China's membership is meaningful. In addition, after becoming a member of the WTO, while the agricultural raw material sector was the least specialized and the lowest competitive sector in Chinese exports, the sector with the highest competitive power was its mechanical electronic devices and machinery. In other words, after the WTO membership, it is seen that China's total exports increased approximately 10 times during 2001.
\end{abstract}

Keywords: WTO, People's Republic of China, clustering analysis method, export, globalization. JEL Codes: F10, F13.

\section{INTRODUCTION}

Even though economies have faced significant cyclical fluctuations recently, all countries around the world have reached unimaginable growth rates. This growth is witnessed in Asian economies most.

The People's Republic of China, which is among Asian economies, became the growth model leading the world economy in the 21st century and the most studied country due to the developments that speed its growth and the historical background of its growth trend. This rapid transformation process called 'the Chinese miracle' can be viewed in three parts: 1949-1977 Mao era, the 1978-2001 transition period from a closed structure to a modern socialist market economy, and post-2001 reformist policies and growth period. During Mao era, a closed economic system was embraced under the influence of Marxist ideology while a Soviet-type planned economy and development plans were put into effect. In 1978, with Deng Xiaoping coming to power, China opened its doors to the World and embarked on radical process of restructuring towards liberalization and integration into the capitalist system.

Many factors have an impact on China's success and trade gains, such as the direct flow of capital into the country, exchange rate policies, human capital investments, private economic zones, and export-based development strategies. Today, China has become

${ }^{1}$ This study is a part of the second author's MA thesis supervised by the first author. 
the world's largest exporter and the second largest importer. It has become a major investment, cooperation and trading partner of other countries.

China's growth and trading volume had also positive effects on other countries regarding exports and imports. In line with these strategies and policies, China, which actively participated in membership and cooperation activities in international organizations, and the country wants to have a voice in the international arena. The most important one among these organisations is the membership of World Trade Organization (WTO); the sustainable growth in the Chinese economy has made significant contributions in increasing the volume of foreign trade and becoming a super power in the world.

Although the membership of China in WTO and its competitive advantage are perceived as a risk for the USA and the countries that have a say in the world economy, China's pro-harmony and peace policies have been eliminating this perception. In this battle for gaining competitive advantages, the process should be followed closely and the domino effect of the steps taken should be kept in mind. The main purpose of this study is to evaluate the export-oriented general economic structure of China, which alone meets $20 \%$ of world exports today, and it is to examine the country's sustainability of growth rates which have been over $8 \%$ for many years. In addition, the examination of the policies followed reveals the changes and the cluster differences in the group of export products before and after its membership to the WTO.

\section{CHINESE ECONOMY IN THE HISTORICAL PROCESS}

\subsection{People's Republic of China (1949-1977)}

With Mao, who came to power in 1949, a closed economic order based on strict central planning prevailed in the People's Republic of China until 1978. Once Mao came to power, the Chinese economy did not do well. Mao first implemented the first five-year development plan in 1953 with the Soviet-type planned economy and received technical support from the Union of Soviet Socialist Republics in this process. (Naughton 2007: 66).

In the first five-year development plan, high growth rates were targeted especially with the development of heavy industry and this goal was achieved (Özsoylu 2006: 9-10).

With the second five-year development plan, which was put into effect in 1958, the rapid transition from the pre-1949 agricultural feudalism to communism was aimed, and its "Special Agricultural Production" was completely banned (Yang 1996: 35).

It is seen that the goals of the third five-year development plan implemented in 1966 were the national defence investments in the country. The fourth and fifth development plans were put into practice in the period of 1971-1980. (Tan 2006: 10).

\subsection{The Period of $1978-2001$}

With Deng Xiaoping taking power in 1978, a reformist process began, which was described as a turning point in Chinese history. Over time, the Chinese economy gave up its introverted centralist structure and attained an open modern socialist market economy (Öğütçü 1998: 68).

The basic development program of the new era was based on the concept of quadruple modernization. As well as foreseeing modernization in the fields of industry, agriculture, national defence, science and technology, this concept envisioned its achieving progress with open strategies and policies instead of closed ones. Since 1978, a series of legal regulations has been made in order to form/build a steady foundation for the improvement of foreign investment, money and capital markets all together with the free market system (Tan 2006: 6-9).

In addition, the applied external planning system in foreign trade was gradually abolished at first, and by the 2000s it was completely abandoned. While the government maintained its control in foreign trade, most of the trade became determined by the market. This resulted in an enormous increase in the number of companies dealing with foreign trade (Huang and Wang 2004:336-337).

While the foreign trade figures of China increased regularly during the reformist process, a radical change process was experienced in the goods subject to foreign trade. China, whose foreign trade was almost non-existent in the previous periods, showed a tenfold growth in the period of 1949-1978. While this rate increased approximately fifty times in the period of 1978-2001. Besides, while the share of primary goods in total exports was $51 \%$ in the first years of the reform, the share of the capital-intensive processed goods increased greatly after 1986, reaching 74\% in 1990 and 90\% of total exports in 2002 (Pingyao 2004: 38-50). 


\subsection{1 and the Following Years}

2001 was a turning point for the Chinese economy. Although the reforms carried out since 1978 provided a certain growth and economic development in China, on a global basis they do not reach the targeted point. The country, which hosts $1 / 8$ of the world population, is in demand for exports with economic reforms, but it is limited in the production of original products due to the production of counterfeit or similar products. In addition, during this period, trade partners are primarily neighbouring countries. It cannot be said that China had a significant influence on central economies during this period (Becker 2007: 35).

After China's membership in the World Trade Organization in 2001, the growth in exports reached 30\% on average. China, which was seen as a more reliable supplier with its admission to the WTO, became more effective in the markets. In 2005, with quotas being lifted in the textile sector, the economic breakthrough started moving forward (Lim 2006: 29).

The membership of WTO provided a wide range of imports. There was a significant increase in world oil imports, especially due to the increasing demand of China, which is dependent on capital goods and raw materials. Apart from that, with a population of 1.386 billion, China has a great market potential in terms of consumer goods. In addition, market expansions to be provided by China in line with the increasing demand in service sectors such as financial services and telecommunication provide significant gains to the developed countries (Porath 2004: 48).

\section{CHINA'S MACROECONOMIC STRUCTURE}

\subsection{Growth}

The revolutionary movement that started with Mao in 1949 lasted until 1978, and the People's Republic of China, which achieved some high growth rates thanks to the policies of market openness after 1978 and the reforms in the market economy. This brought the country from being an underdeveloped country to being the second fastest growing country in the World. Thus, China became the centre of attention for the countries of the world. (Angresano 2005: 472).

The Chinese economy, which had a growth rate of $9 \%$ in the 1990 s, managed to keep its growth in the $10-13 \%$ range through its openness to new export markets after its admission to the WTO in 2001. The growth figures, which started to shrink partially in 2012, remained at the level of 6\% in the period of 2015-2016 and 2017.

On the other hand, its GDP, which was $\$ 863.7$ million in 1996, had doubled until 2001, and reached \$1.339 million. China, whose GDP continues to increase with each passing year after its membership of the WTO in 2001, increased its GDP approximately 3.43 times from $\$ 1.339$ million in 2001 to $\$ 4.594$ million in 2008 . As a result of its membership to the WTO, the GDP figures increased 10.16 times in 17 years, and the amount reached $\$ 13.610$ million in 2018.

Table 1: The Sectoral Shares of Chinese GDP (\%)

\begin{tabular}{|c|c|c|c|}
\hline Years & Agriculture & Industry & Service \\
\hline 2008 & 10,1 & 46,9 & 42,8 \\
\hline 2009 & 9,6 & 45,9 & 44,4 \\
\hline 2010 & 9,3 & 46,4 & 44,1 \\
\hline 2011 & 9,1 & 46,5 & 44,2 \\
\hline 2012 & 9,1 & 45,4 & 45,4 \\
\hline 2013 & 8,9 & 44,1 & 46,8 \\
\hline 2014 & 8,6 & 43,2 & 48,1 \\
\hline 2015 & 8,4 & 41,1 & 50,4 \\
\hline 2016 & 8,1 & 40,1 & 51,8 \\
\hline 2017 & 7,5 & 40,5 & 52,1 \\
\hline 2018 & 7,0 & 39,7 & 53,3 \\
\hline
\end{tabular}

Source: World Bank, OECD National Data, (E.T: 29.11.2020)

In Table-1, the sectoral shares of China's GDP between 2008-2017 are given. Between 2008 and 2017, the share of the agricultural sector in GDP declined on average, although it remained at constant rates. China, which has experienced significant developments in the name of industrialization for the last 30 years, has seen small declines in the share of the industrial sector in GDP from year to year, while the share of the service sector is increasing. While the share of the service sector in GDP was around $42.8 \%$ in 2008 , this ratio increased to $48 \%$ in 2014 and $52.1 \%$ in 2017. 


\subsection{Investments}

Foreign investments are of great importance as a determining factor in the economic growth process for all countries. The openness of countries to foreign investment is proportional to their growth potentials. After the 1978 reforms, China became a sought-after country for any investments through the autonomous free zones it created. The main reasons for this include its liberalization, economic structure, incentives, cultural environment, cheap labour and tax advantages. Moreover, the increasing trade potential following WTO membership has also been effective in attracting investments to the country (Knight, Song 2005: 9), (Tseng, Zebregs 2002: 8).

In addition, while the growing Chinese economy invests in its own country, it also makes investments around the world. The majority of China's foreign investments are distributed over seven countries or regions, including China's Hong Kong Special Administrative Region, ASEAN, EU, USA, Russia, Africa and Japan. This increase is attributed to the formation of a strong capital created by the growing economy, the transition from importing technology to exporting, and the competitive power of companies (Knight, Song 2005: 9).

\subsection{Employment and Workforce Structure}

China's globalized economy created a dual structure in its workforce, namely agricultural poor workforce and industrial rich workforce (Knight, Song 2005: 3).

In the sectoral distribution of employment, the share of agriculture in its total employment was $42.6 \%$ in $2017,25.2 \%$ of industry and $32.2 \%$ of the tertiary sector (National Bureau of Statistics Of China ET: 27.10.2018). China with $42.6 \%$ share of agriculture within employment is at the same level as the low-middle income countries such as Sri Lanka, Indonesia and Thailand are. Among high income countries such as the USA, Japan, Canada, Australia and the EU, the share of agriculture in employment is $4.9 \%$ on average. While the shares of industry and service sectors of employment in China are $25.2 \%$ and $32.2 \%$ on average, the shares of industry and service sectors of employment in high-income countries are $24.5 \%$ and $71.8 \%$, respectively. A significant portion of the Chinese population lives in rural areas and is employed in agriculture. The productivity of its agricultural workers is very low too. China's membership to the WTO directly affected the structure of employment in agriculture. The share of the work force, the working rate in the industry and service sector as well as those with the rising income level in employment increased. It is observed that the increase in foreign capital investments provided by open door policies affects unemployment rates directly. Following open door policy and foreign capital investments, [China's] unemployment rate dropped to $1.8 \%$ in 1985 (Zhu 2005 : 21).

\subsection{Inflation}

When the prices were determined by the state in China before 1978, there was no inflation. After 1978, inflation started to pose a problem for the country and this continued until 1997 (Wong and Ding 2002: 11-13).

One of the most important reasons for post-1978 inflation is the reform of the state's economic policies and the country's rapid economic growth with the reforms. Its inflation rate reached double digits in the period of 1986-1990 when reforms accelerated and radical economic practices were implemented to attract foreign direct investment to the country (Pingyao 2006: 15-29).

A significant decline in prices started in China in 1996-2002, and the economy was in recession. The boom in the economy, which began with the effect of the WTO membership in 2002, caused increases in prices. With the effect of the 2008 global economic crisis, it is observed that the inflation approached double digits. The actions made by the state regarding investments had a great impact on inflationary fluctuations in China. Therefore, inflation in China did not follow a linear pattern (Pingyao 2006: 15-29).

\subsection{Interest Rates}

In addition to its great success in economic development, China started to develop in banking and finance sectors with compliance with the international banking and financial system, and the increase in foreign capital which the country attracted. In this successful process, aggregate demand management, sustainability of growth and interest rate policies were fundamental mechanisms in controlling inflation (Doğru 2016: 39).

\subsection{Distribution of Income}

The economic growth in China initially revealed a significant income inequality, increasing the inequality in income distribution between regions and groups (Zhuang, Li 2016: 2). The income inequality was considered as normal after the reforms and the rapid growth in the country. The growth is often related to early stages of progress in certain sectors and regions. Its income inequality occurs as leading sectors and regions develop more than others do. During the transition period from the socialist planned 
economy, which is characterized by egalitarian wage and income distribution systems in China, to a free market economy, created inequality. The risk and uncertainty in markets, income difference, occurred between individuals depending on productivity, human capital, entrepreneurship and wealth (Shi vd. 2008: 42).

Another indicator of income distribution in China is the rate of poverty. The rate, which was quite high in the early 1980 s, was in a downward trend due to the economic development in the country, and it decreased to $6 \%$ in 2015 .

Its poverty is higher in rural areas and the western China than anywhere. Until 2004, its poverty was $9 \%$ in coastal areas and $22 \%$ in inland regions. In 2004, according to the poverty threshold of $\$ 1.5$ a day, the number of poor rural people in coastal areas (11\%) was less than a third of its level in 1989 . Over the same period, the urban poverty in coastal areas fell from $16 \%$ to $6 \%$. The urban poverty in inland regions fell from $27 \%$ in 1989 to $18 \%$ in 2004 while the rural poverty fell more rapidly, by half, from $47 \%$ to $24 \%$.

\section{THE GENERAL STRUCTURE OF CHINESE FOREIGN TRADE}

With the high growth experienced in China in the 1980s, an increase in trade volume was observed. These developments in China led to some changes in the international and local areas. China's close follow-up of scientific and technological developments and the implementation of some reforms accelerated its adaptation process to the world economy. This rapid economic growth that dominated China after its WTO membership and the desire to take advantage of the emerging opportunities paved the way for incentives to be given to the foreign investors. With the withdrawal of foreign investments from the country, it contributed to the elimination of the deficit in capital and technology, and thus new production techniques began to be used in domestic industries. In line with these developments, China's trade volume, which was $\$ 29.2$ billion in 1979, reached $\$ 3.86$ trillion in 2012, and for the first time in 2014, its foreign trade volume exceeded \$4 trillion, and China became the first country in the world with the largest foreign trade volume (China Country Bulletin, http://www.etonet.org.tr/uploads/cin.pdf ET: 05.01.2019), thus the most dynamic and fastest growing sector in the country was the foreign trade sector.

Table 2: China's Foreign Trade Indicators (Million Dollars)

\begin{tabular}{|l|l|l|l|l|l|l|l|}
\hline Foreign Trade Indicators & $\mathbf{2 0 1 2}$ & $\mathbf{2 0 1 3}$ & $\mathbf{2 0 1 4}$ & $\mathbf{2 0 1 5}$ & $\mathbf{2 0 1 6}$ & $\mathbf{2 0 1 7}$ & $\mathbf{2 0 1 8}$ \\
\hline Imports & 1.818 .405 & 1.949 .990 & 1.959 .233 & 1.681 .951 & 1.587 .431 & 1.840 .957 & 2.134 .983 \\
\hline Exports & 2.048 .714 & 2.209 .005 & 2.342 .293 & 2.274 .949 & 2.098 .161 & 2.271 .796 & 2.494 .230 \\
\hline Foreign Trade/GDP (\%) & 48,1 & 46,6 & 45,7 & 40,5 & 37,1 & 38,8 & 34.0 \\
\hline Exports / imports (\%) & 169 & 172 & 173 & 169 & 163 & 123 & 116 \\
\hline Foreign Trade Volume & 3867.119 & 4.158 .995 & 4.301 .526 & 3.956 .900 & 3.685 .592 & 4.112 .753 & 4.629 .213 \\
\hline
\end{tabular}

Source: WTO, 2019; The World Bank, 2019, https://wits.worldbank.org/countrysnapshot/en/CHN (ET:02.12.2020)

In the period from 2000 to 2013, China achieved a three-fold increase in its exports of goods, increasing its share in world exports from $3.8 \%$ to $12.1 \%$. The World Bank estimates that this ratio will be around $20 \%$ by 2030 (The World Bank 2014).

In Table-2, China's 2012-2017 export, its import values, its foreign trade volume, the ratio of exports to imports and the percentage share of foreign trade in GDP are given. The import value, which was $\$ 1.818 .405$ million in 2012 , showed a dramatic increase in 2014 and reached $\$ 1.959 .233$ million. Meanwhile, the change in exports was recorded as $\$ 2.048 .714$ million in 2012 , while this figure reached $\$ 2.342 .293$ million in 2014 with a significant increase. With the increase in global competition and product diversity, there was a decrease in import and export figures in 2016 and an increase in the following year, in 2017.

The main reason for China's high export volume and its global leadership is due to the rapid diversification in the export market. Along with the diversification in the export market, the diversification of export products emerged as well (Jarreau, Poncet 2009: 2). In addition, its direct foreign investments, WTO membership, effective use of the global value chain, low exchange rate policy and special economic zones are among the determining factors for China's success in exports (Çelik 2016: 47). 
Figure 1: Major Countries in China's Export (\%)

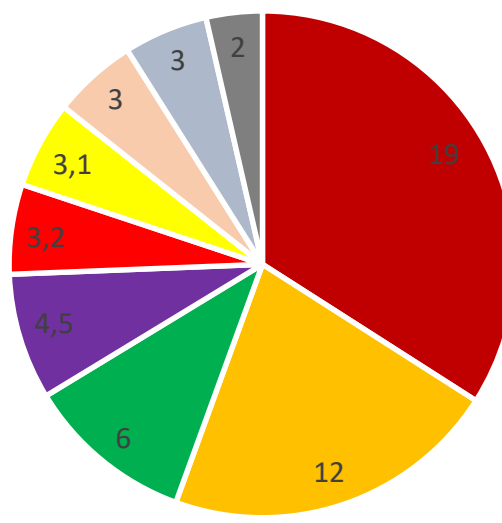

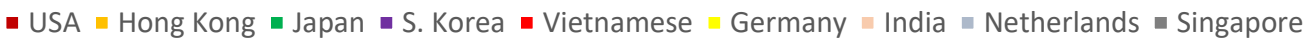

Source: The Global Trade Atlas (2018).

Looking at the major countries to which China exported in 2017, as seen in Figure-1, the USA ranks as the first with the largest export of \$431 billion and a 19\% share. Hong Kong followed the USA with \$280 billion and $12 \%$ share, and Japan with \$137 billion and $6 \%$ share. The other top ten countries to which China exported the most are: South Korea, Vietnam, Germany, India, the Netherlands and Singapore in order. In 2019, Turkey ranked 28th with $\$ 18$ billion and $0.8 \%$ respectively.

In 2017, the broadcast equipment ranked first with 9.6\%, and its computer exports ranked second with 6.1\%. At the same time, China was the world's second largest importer after the USA, with $\$ 1.84$ trillion in 2017. The import figures of $\$ 1.42$ trillion in 2012 reached $\$ 1.4$ trillion in 2019 and a 1.2\% increase was achieved. https://oec.world/en/profile/country/chn/\#Trade_Balance (ET: 25.07.2019).

Besides, most of China's imports are raw materials and intermediate goods. Since these imported goods are converted into final products and re-exported within the country, the increase in exports also affects the import (Sandıklı 2005: 305). Among the most imported products, the integrated circuits (telephone, office machine parts, semiconductor devices, broadcast accessories) ranked first with 13.5\%, while crude oil was the second largest import product with 9.4\% (https://oec.world/en/profile/country/chn/\#Trade_Balance (ET: 25.07.2019).

Figure-2, on the other hand, shows the main countries from which China imported in 2017. Accordingly, the most imports were from South Korea with $\$ 177$ billion and $9.6 \%$ share. This country was followed by Japan with $\$ 165$ billion and $9 \%$ share and the USA with 154 billion dollars share $8.4 \%$. Turkey ranked 54 with $0.2 \%$ share and nearly $\$ 4$ billion. 
Figure 2: Major Countries in China's Import

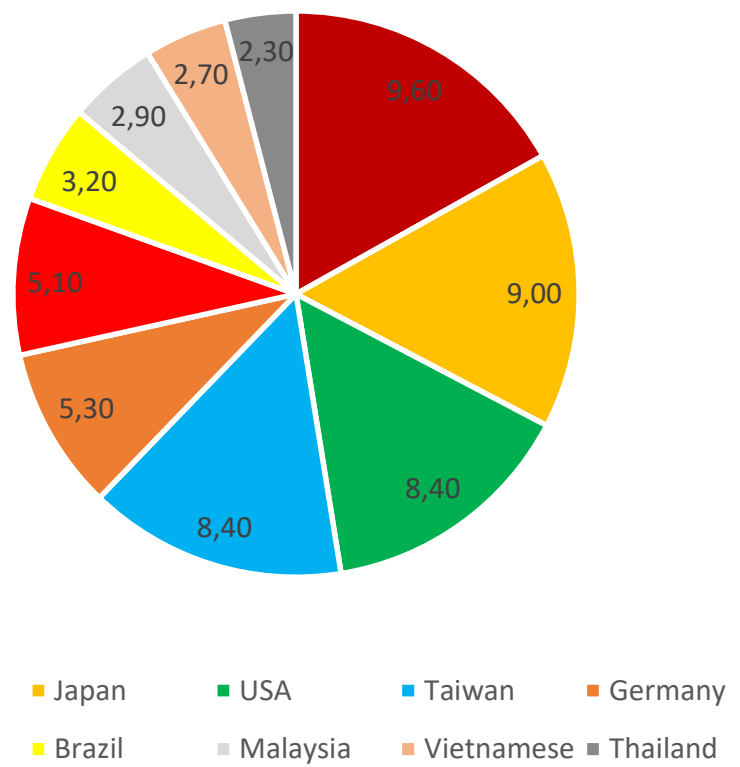

Source: The Global Trade Atlas (2019).

\section{DETERMINING PRODUCT DIVERSITY IN CHINA'S EXPORT SECTOR BY CLUSTERING ANALYSIS (2001-2017)}

\subsection{Literature Review}

Amighini (2005) investigated China's place in the world market in information-communication technologies industries. Balassa's Announced Comparative Advantage Index and net trade index were used to analyse 1991 and 2001, and the SITC five-digit trade classification was used. It was observed that China had disadvantages in technology-intensive sectors where it specialized in unskilled labour-intensive sectors between 1991 and 2001. In addition, it was determined that competitive power increased in some selected sub-sectors. Since the 1990s, the competitive power in technology-intensive sectors has been increasing. Specifically, it increased in the electronics, machinery, informatics, telecom and office equipment and electrical goods in the last decade. It is revealed that the foreign capital investments entering the country and the country's global production networks play an active role in the developments in information and communication technologies. In this cluster analysis, the emphasis on electronic products and machinery sector in China for the period of 1992-2001 is in line with the increase of China's competitiveness in these sectors after its WTO membership, with the aim of focusing on high technology products after 2001.

Veeramani (2006) has made a comparative analysis of the changing patterns of exports and specialization in India and China since 1980. The 1980-2003 period was taken into account in the analysis, the factor intensity of China and India were calculated by using SITC Rev.3. It was observed that China and India had comparative advantages in labour intensive goods in line with their factor endowment. The comparative advantage of both countries in technology-intensive goods was low. The comparative advantage in human capital and technology-intensive goods was gradually increasing in both countries. Compared to India, China had more comparative advantages in terms of technology-intensive products and unskilled labour. In addition, in the study, it is stated that India specialized in agricultural raw materials, mineral resources and low quality labour-intensive goods; China, on the other hand, was observed to specialize in unskilled labour-intensive and agricultural raw material-intensive goods, although it has decreased in recent years. As a result of our study, China's high competitive power in labour-intensive products is in line with Veeramani's work in terms of its orientation towards technology-based exports while it is not similar in the agricultural raw materials sector which indicates that specialization in exports and competitiveness are minimal.

Özer and Çiftçi (2009) analysed the relationship between R\&D expenditures and general exports, information communication technologies exports and advanced technology exports in 19 OECD countries in the period of 1993-2005 by using panel data analysis in their studies. Since high-tech products are products that create added value in the country's exports, it was determined 
that the shifting of R\&D expenditures from low-tech products to high-tech products had a positive effect on high-tech product exports.

Kosekahyaoglu and Ozdamar (2011) studied the competitiveness of the 1990-2009 period based on labour-intensive, raw-material intensive, capital intensive, research-based goods that can be imitated easily and the goods which are hard to imitate in five categories through the results in Turkey, China and India. The Revealed Comparative Advantage Index, Export Specialization Index and Comparative Export Performance Index were used to measure the competitiveness of these countries. As a result, it was observed that competitiveness in these countries was high in labour-intensive goods, but the importance of capital-intensive goods has gradually increased in India recently. In addition, labour-intensive goods that can be replicated across China's Turkey is not very advantageous and easy, while across India, it was found to have a better export expertise in capital-intensive goods than raw materials and easily imitated goods.

Han and Lee (2012) examine how much of the foreign trade between China and Korea took place in the form of vertical intraindustry trade. In this study, the relevant data were taken from the United Nations Comtrade database using the International Standard Trade Classification Rev.5 product grouping. In the analysis made, it was seen that approximately $50 \%$ of the trade between China and Korea from 1990 up to date was in the form of intra-industry trade. The analysis showed that most intraindustry trade takes place in the form of vertical intra-industry trade. However, it was determined that this condition varies in some sectors. It was determined that since the $2000 \mathrm{~s}$, while horizontal intra-industry trade has increased in the chemical industry, vertical intra-industry trade has been decreasing. On the other hand, it is observed that the vertical intra-industry trade increased in textile, fabricated metal and machinery industry and electronics industry, but horizontal intra-industry trade decreased.

Bulum et al. (2013), in their cluster analysis study conducted by WTO member countries on international trade volumes, the countries were divided into groups through Ward's method which is applied in hierarchical cluster analysis, and the Squared Euclidean distance was preferred for the measurement of distance. Considering the import and export figures, it is seen that following the USA, which was the leading country in international trade volume, came China and Germany. Taking the export figures alone into consideration, it is determined that China surpassed the USA and Germany. It is that China has an important position in international trade volume, but when the population criterion is taken into account, the foreign trade returns are disproportionately distributed among the country's population. The evaluations made in China are in line with the results reached in our study.

In his study, Şahin (2015) analysed the export structures of Turkey and BRIC (Brazil, Russia, India, China) according to density factor, and compared the comparative advantages of Turkey's labour-intensive goods exports for the period of 1992-2013 with BRIC countries. In the study, the Revealed Comparative Advantage Index (RCA) was used in the analysis of competitiveness in labour-intensive goods. The 1992- 2013 data analysed and results were made within the scope of the SITC Rev. 3 double-digit product group. Turkey, China and India's labour intensity factor was found that it consists of intensive goods. While Brazil's factor density consists of capital-intensive and raw material-intensive goods; Russia's factor density consists of raw material-intensive goods. In addition, Turkey, China and India had high competitiveness in labour-intensive goods; Russia's labour-intensive goods found to have low competitiveness. For Brazil, it is observed that the competitiveness of labour-intensive goods was higher than Russia but lower than the other countries.

Şahin (2017) analyses the effect of labour-intensive goods on foreign trade volume in ASEAN-5 countries covering the years of 2000-2014. The level of intra-industry trade of labour-intensive goods and the competitiveness of labour-intensive goods were analysed. While the Revealed Comparative Advantage Index (RCA) is used in the measurement of competitiveness, the GrubelLloyd Index $(G L)$ is used in the measurement of intra-industry trade. As a result of the study, it is determined that the level of intraindustry trade in labour-intensive goods was high. In the competitiveness analysis, Indonesia and Thailand were highly competitive in labour-intensive goods; It is determined that Malaysia, Singapore and the Philippines were less competitive.

Ervani et al. (2018), in their study based on the years of 1995-2015 on Indonesia's east Asian export models, reach that there was a competition with Japan, China, Hong Kong, Korea and Singapore. The data used in this study is obtained from the UN database, and the three-digit SITC Rev-2 classification is used as a variable. In this study, the country based on the six East Asian countries whose exports are analysed was Indonesia. The general observation of East Asian countries (Indonesia, China, Japan, Hong Kong, South Korea and Singapore) are that they specialized more on product groups with low comparative advantages. According to the research, it is determined that in core products, China had a comparative advantage in labour-intensive products and Japan in technology-intensive products. Although the comparative advantage varied for Korea, Singapore and Hong Kong, it is determined that they had a comparative advantage in technology-intensive products. It is observed that the exports of China, Japan, Korea and Singapore increased in the period of 1995 and 2015, but Indonesia's exports decreased. It is determined that China and Japan 
were a regional threat regarding export prospects, which were major rivals for Indonesia. The specialization model of Hong Kong, South Korea and Singapore offered opportunities for Indonesia's development and export prospects.

\subsection{Method and Findings}

The statistical analysis of the study has been made in SPSS 19.0 software program. In order to show the effect of WTO membership on China's exports, the export data of China in different sectors were evaluated. The aforementioned data were obtained from the World Bank website. A total of 25 different sector definitions obtained from the World Bank between 1992 and 2017 are given in Table 3.

Table 3: Sectors Included in the Analysis

\begin{tabular}{|l|l|l|l|}
\hline $\mathbf{6}$ & Animal & Sector-14(z15) & Mechanics and Electronics \\
\hline Sector-2(z3) & Vegetables & Sector-15(z16) & Shipping \\
\hline Sector-3(z4) & Food products & Sector-16(z17) & Mixed Commercial Goods \\
\hline Sector-4(z5) & Minerals & Sector-17(z18) & Mines \\
\hline Sector-5(z6) & Petroleum products & Sector-18(z19) & Textiles (fabric) \\
\hline Sector-6(z7) & Chemicals & Sector-19(z20) & Machine \\
\hline Sector-7(z8) & Plastics & Sector-20 $(z 21)$ & Raw materials \\
\hline Sector-8(z9) & Hide and leather & Sector-21(z22) & $\begin{array}{l}\text { Commercial intermediate } \\
\text { goods }\end{array}$ \\
\hline Sector-9(z10) & & Sector-22(z23) & Consumer goods \\
\hline Sector-10(z11) & Wooden & Sector-23(z24) & Production goods \\
\hline Sector-11(z12) & Textiles (clothing) & Sector-24(z25) & Agricultural raw material \\
\hline Sector-12(z13) & Shoes & Sector-25(z26) & Agricultural products \\
\hline Sector-13(z14) & Stone, glass & & \\
\hline
\end{tabular}

Non-hierarchical cluster analysis method was used in the study. The cluster numbers were found by looking at the dendogram graph obtained in each analysis. Accordingly, it was determined that there were two clusters before and after the WTO. The difference between sectors was tested with the Mann-Whitney $U$ test and the significance level was taken as 0.05 . In order to show the effect of WTO membership on China's exports, the export data of China in different sectors were evaluated. The aforementioned data were obtained from the World Bank website and a total of 25 different sector definitions obtained from the World Bank between 1992 and 2017. The findings obtained as a result of the analysis made in the study can be summarized as follows, when China's total exports from 1992 to 2017 and the changes in exports in 25 different sectors were examined, it was observed that there was a significant increase in all sectors. These results are given in Table.4 below.

Table 4: Sectoral Analysis Before and After WTO Membership

\begin{tabular}{|l|l|l|c|}
\hline \multirow{2}{*}{} & \multicolumn{2}{|c|}{ WTO Membership } & \multirow{2}{*}{ P value } \\
\cline { 2 - 3 } & Before & After & $<$ \\
\hline Total Exports & $151.0(84.9-249.2)$ & $1430.7(266.1-2342.6)$ & $<0.001$ \\
\hline Animal & $3.8(2.6-4.5)$ & $9.6(4.6-18.7)$ & $<0.001$ \\
\hline Vegetables & $4.7(4.4-6.0)$ & $12.7(5.0-25.9)$ & $<0.001$ \\
\hline Food Products & $4.3(3.3-5.2)$ & $18.2(5.8-30.9)$ & $<0.001$ \\
\hline Minerals & $1.3(0.8-1.6)$ & $3.6(1.4-35.4)$ & $<0.001$ \\
\hline Petroleum Products & $5.2(4.1-7.9)$ & $26.7(8.4-35.4)$ & $<0.001$ \\
\hline Chemicals & $8.4(4.1-11.6)$ & $68.8(12.8-114.3)$ & $<0.001$ \\
\hline Plastics & $4.4(1.8-7.9)$ & $41.5(8.3-91.1)$ & $<0.001$ \\
\hline Hide and Leather & $5.6(2.9-7.5)$ & $18.3(8.4-35.1)$ & $<0.001$ \\
\hline Wooden & $3.2(1.7-4.5)$ & $21.9(4.9-40.2)$ & $<0.001$ \\
\hline
\end{tabular}




\begin{tabular}{|l|l|l|c|}
\hline Textiles (clothing) & $35.9(24.6-49.4)$ & $179.7(49.8-287.6)$ & $<0.001$ \\
\hline Shoes & $8.5(5.1-12.0)$ & $36.0(12.3-70.5)$ & $<0.001$ \\
\hline Stone, Glass & $4.4(2.2-6.6)$ & $31.1(6.6-112.3)$ & $<0.001$ \\
\hline Metals & $12.1(4.6-16.6)$ & $115.7(16.1-184.3)$ & $<0.001$ \\
\hline Mechanics and Electronics & $31.1(11.5-72.9)$ & $610.6(84.9-981.0)$ & $<0.001$ \\
\hline Shipping & $4.2(1.8-9.3)$ & $70.7(9.4-109.1)$ & $<0.001$ \\
\hline Mixed Commercial Goods & $15.6(8-26.9)$ & $132.7(27.4-240.1)$ & $<0.001$ \\
\hline Mines & $3.1(1.4-4.6)$ & $21.9(4.6-29.3)$ & $<0.001$ \\
\hline Textiles (fabric) & $39.0(26.4-53.5)$ & $188.3(54.5-302.3)$ & $<0.001$ \\
\hline Machine & $35.3(13.2-82.5)$ & $677.7(94.9-1115.1)$ & $<0.001$ \\
\hline Raw Materials & $11.8(10.1-13.4)$ & $30.7(13.9-41.3)$ & $<0.001$ \\
\hline Commercial Intermediate Goods & $33.8(16.8-42.8)$ & $246.7(44.0-385.4)$ & $<0.001$ \\
\hline Consumer Goods & $80.2(47.5-123.6)$ & $497.6(127.4-901.3)$ & $<0.001$ \\
\hline Production Goods & $27.1(8.6-68.5)$ & $632.8(80.3-1022.9)$ & $<0.001$ \\
\hline Agricultural Raw Material & $2.5(1.9-2.8)$ & $5.9(2.4-10.0)$ & $<0.001$ \\
\hline Agricultural Products & $127.3(66.8-129.9)$ & $1331.8(235.9-2202.7)$ & $<0.001$ \\
\hline Ne: Valyes rer to & & \\
\hline
\end{tabular}

Note: Values refer to Median value (minimum-maximum), $\mathrm{p}$ values refer to Mann Whitney $\mathrm{U}$ test results.

*Export values are given as "Million Dollars".

The Mann-Whitney $U$ test was used to investigate whether there was any difference between sectoral analysis variables before and after WTO membership. It can be said that there was a difference between all variables before and after WTO membership $(p<0.05)$.

Between 1992 and 2017, export items were evaluated through individual clustering analysis before and after the WTO membership in order to determine the sectors that were close to each other. Accordingly, the results were obtained separately for before and after the WTO membership.

Pre-membership clustering results were interpreted with a dendrogram chart in Figure 3. 
Figure 3: A Dendogram Chart before WTO Membership

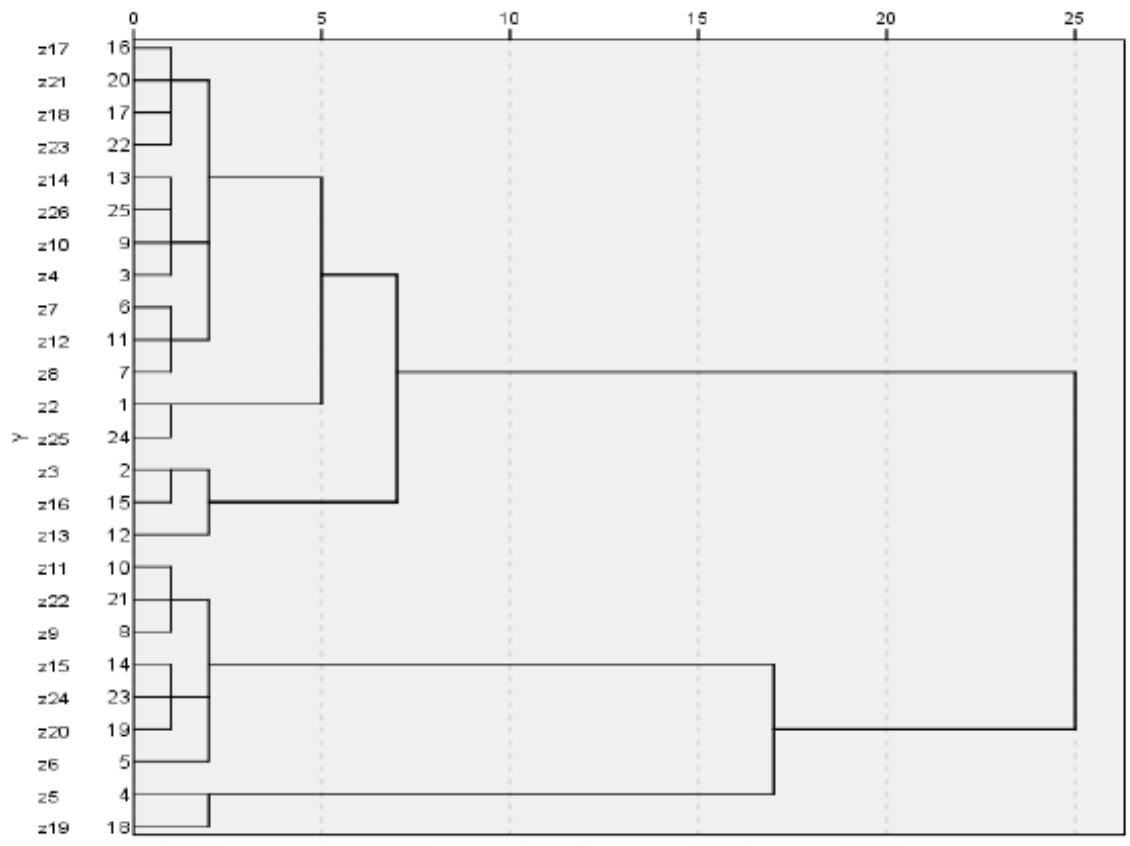

Sector groups are clustered in Table- 5 according to pre-membership clustering results.

\section{Table 5: Sector Groups Before WTO Membership}

\begin{tabular}{|l|l|l|l|}
\hline Z2 & Animal & Z15 & Mechanics and Electronics \\
\hline Z3 & Vegetables & Z16 & Shipping \\
\hline Z4 & Food products & $\mathrm{Z} 17$ & Mixed Commercial Goods \\
\hline Z5 & Minerals & $\mathrm{Z} 18$ & Mines \\
\hline Z6 & Petroleum products & $\mathrm{Z} 19$ & Textiles (fabric) \\
\hline Z7 & Chemicals & $\mathrm{Z} 20$ & Machine \\
\hline Z8 & Plastics & $\mathrm{Z} 21$ & Raw materials \\
\hline Z10 & Hide and leather & $\mathrm{Z} 22$ & Commercial Intermediate Goods \\
\hline Z11 & Wooden & $\mathrm{Z} 23$ & Consumer goods \\
\hline Z12 & Textiles (clothing) & $\mathrm{Z} 24$ & Production Goods \\
\hline Z13 & Shoes & $\mathrm{Z25}$ & Agricultural Raw Material \\
\hline Z14 & Stone, Glass & $\mathrm{Z26}$ & Agricultural Products \\
\hline
\end{tabular}

Accordingly, the cluster results are as follows:

CLUSTER-1: Z2. Z3 Z4 Z7 Z8 Z10. Z12. Z13. Z14. Z16. Z17. Z18 Z21. Z23. Z25. Z26

CLUSTER-2: Z5. Z6 Z9. Z11. Z15. Z19. Z20. Z22. Z24

Similarly, the dendogram and clustering results for the sector groups after WTO membership are given in Figure 4 and Table 6. 


\section{Figure 4: Dendogram Chart after WTO Membership}

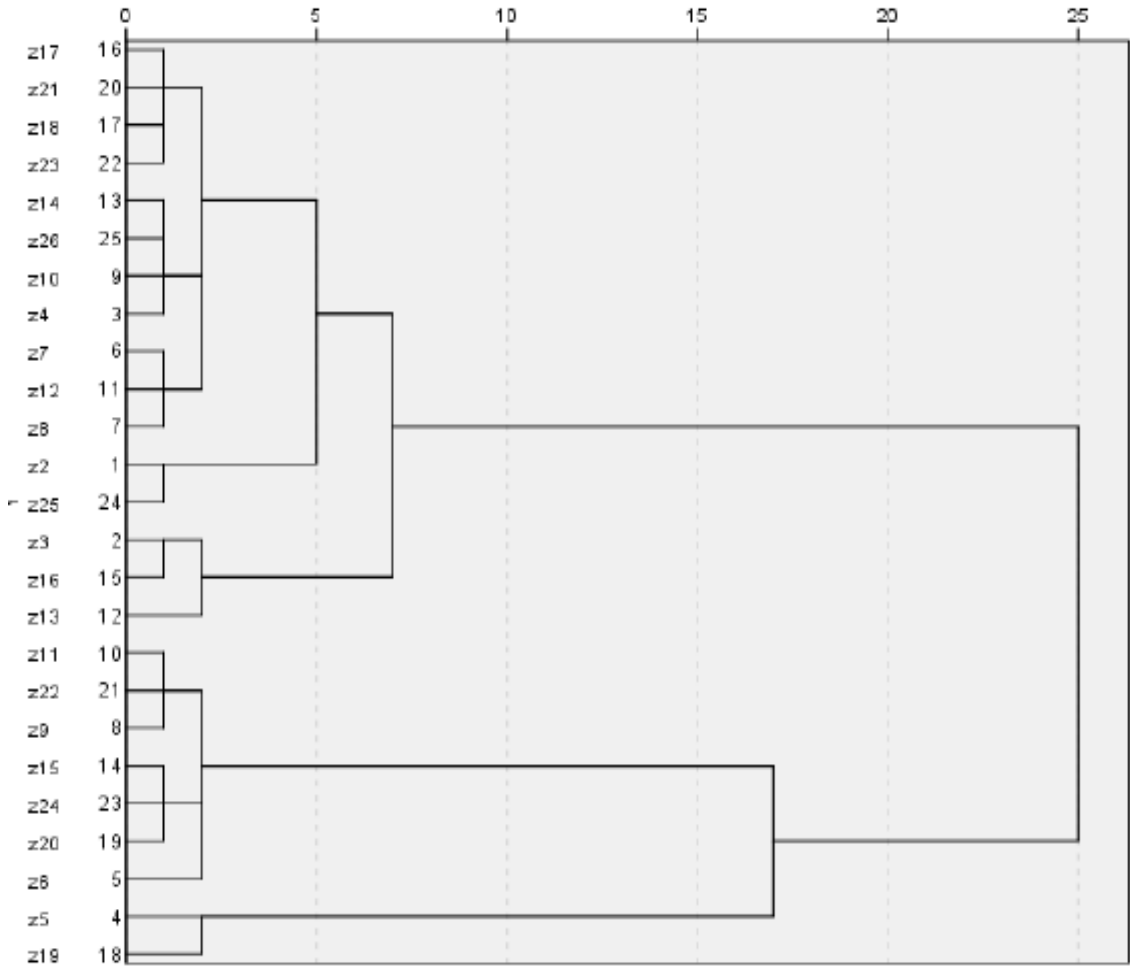

Table 6: Sector Groups after WTO Membership

\begin{tabular}{|l|l|l|l|}
\hline Z2 & Animal & Z15 & Mechanics and Electronics \\
\hline Z3 & Vegetables & Z16 & Shipping \\
\hline Z4 & Food products & Z17 & Mixed Commercial Goods \\
\hline Z5 & Minerals & Z18 & Mines \\
\hline Z7 & Petroleum products & Z19 & Textiles (fabric) \\
\hline Z8 & Chemicals & Z20 & Machine \\
\hline Z9 & Plastics & Z21 & Raw materials \\
\hline Z10 & Hide and leather & Z22 & Commercial intermediate goods \\
\hline Z11 & Wooden & Z23 & Consumer goods \\
\hline Z12 & Textiles (clothing) & Z24 & Production goods \\
\hline Z13 & Shoes & Z25 & Agricultural raw material \\
\hline Z14 & Stone, glass & Z26 & Agricultural products \\
\hline
\end{tabular}

According to the clustering results, it was seen that clothing textile, fabric textile, machinery, petroleum products, commercial intermediate goods, leather-skin and production goods were together in industrial and production sectors.

The cluster results obtained before and after the WTO are given with export data in Table 7 and Table 8. 
Table 7: Cluster Groups and Export Data Before WTO Membership

Group 1

\begin{tabular}{|l|l|c|}
\hline & Sectors & Export (Million \$) \\
\hline $\mathbf{1}$ & Minerals & 1.3 \\
\hline $\mathbf{2}$ & Petroleum Product & 5.2 \\
\hline $\mathbf{3}$ & Hide and leather & 5.6 \\
\hline $\mathbf{4}$ & Textiles (Fabric) & 39 \\
\hline $\mathbf{5}$ & Textiles (Clothing) & 35.9 \\
\hline $\mathbf{6}$ & Mechanics and Electronics & 31.1 \\
\hline $\mathbf{7}$ & Machine & 35.3 \\
\hline $\mathbf{8}$ & Commercial intermediate goods & 33.8 \\
\hline $\mathbf{9}$ & Production goods & 27.1 \\
\hline
\end{tabular}

Group 2

\begin{tabular}{|l|l|c|}
\hline & Sectors & Export (Million \$) \\
\hline $\mathbf{1}$ & Animal & 3.8 \\
\hline $\mathbf{2}$ & Vegetables & 4.7 \\
\hline $\mathbf{3}$ & Food Products & 4.3 \\
\hline $\mathbf{4}$ & Chemicals & 8.4 \\
\hline $\mathbf{5}$ & Plastics & 4.4 \\
\hline $\mathbf{6}$ & Wooden & 3.2 \\
\hline $\mathbf{7}$ & Shoes & 8.5 \\
\hline $\mathbf{8}$ & Stone, Glass & 4.4 \\
\hline $\mathbf{9}$ & Consumer Goods & 80.2 \\
\hline $\mathbf{1 0}$ & Shipping & 4.2 \\
\hline $\mathbf{1 1}$ & Agricultural Products & 127.3 \\
\hline $\mathbf{1 2}$ & Mines & 3.1 \\
\hline $\mathbf{1 3}$ & Raw Materials & 11.8 \\
\hline $\mathbf{1 4}$ & Metals & 12.1 \\
\hline $\mathbf{1 5}$ & Agricultural Raw Material & 2.5 \\
\hline $\mathbf{1 6}$ & Mixed Commercial Goods & 15.6 \\
\hline
\end{tabular}

Considering the Table 7, some sectors in the two groups that existed prior to the WTO membership changed places after China joined the WTO (Table-8.). It is notable that sectors that were in the first group before the WTO such as textile (clothing), mechanical electronics, machinery, commercial intermediate goods and production goods, have demonstrated a substantial rise in export figures after the WTO, approaching the predominant final goods shown in the second group sectors.

Similarly, according to the differences between clusters before and after the WTO, in Tables 7 and 8 , it is seen that food products and the sectors depending on industrialization and industrial development formed two separate clusters. It is viewed that a few sectors shifted towards the groups that they converged in terms of content and export figures before and after the WTO membership. In general, it is determined that two main clusters exist after WTO membership. 
Table 8: Cluster Groups and Export Data after WTO Membership

Group 1

\begin{tabular}{|c|l|c|c|}
\hline & Sectors & Export (Million \$) & Amount of Increase \\
\hline $\mathbf{1}$ & Minerals & 3.6 & 2.7 \\
\hline $\mathbf{2}$ & Petroleum Products & 26.7 & 5.1 \\
\hline $\mathbf{3}$ & Hide and Leather & 18.3 & 3.2 \\
\hline $\mathbf{4}$ & Textiles (Fabric) & 188.5 & 4.8 \\
\hline $\mathbf{5}$ & Mines & 21.9 & 7 \\
\hline $\mathbf{6}$ & Raw Materials & 30.8 & 2.6 \\
\hline $\mathbf{7}$ & Metals & 115.7 & 9 \\
\hline $\mathbf{8}$ & Agricultural Raw Materials & 5.9 & 2.3 \\
\hline $\mathbf{9}$ & Mixed Commercial Goods & 132.7 & 8.5 \\
\hline
\end{tabular}

\section{Group 2}

\begin{tabular}{|c|l|c|c|}
\hline & Sectors & Export (Million \$) & Amount of Increase \\
\hline $\mathbf{1}$ & Animal & 9.6 & 2.5 \\
\hline $\mathbf{2}$ & Vegetables & 12.7 & 2.7 \\
\hline $\mathbf{3}$ & Food Products & 18.2 & 4.2 \\
\hline $\mathbf{4}$ & Chemicals & 68.8 & 8.1 \\
\hline $\mathbf{5}$ & Plastics & 41.5 & 9.4 \\
\hline $\mathbf{6}$ & Wooden & 21.9 & 6.8 \\
\hline $\mathbf{7}$ & Shoes & 36 & 4.2 \\
\hline $\mathbf{8}$ & Stone, Glass & 31.1 & 7 \\
\hline $\mathbf{9}$ & Consumer Goods & 497.9 & 6.2 \\
\hline $\mathbf{1 0}$ & Shipping & 7.7 & 16 \\
\hline $\mathbf{1 1}$ & Agricultural Products & 1331.9 & 10 \\
\hline $\mathbf{1 2}$ & Textiles (Clothing) & 179.7 & 5 \\
\hline $\mathbf{1 3}$ & Mechanics and Electronics & 610.6 & 19.63 \\
\hline $\mathbf{1 4}$ & Machine & 677.7 & 19.19 \\
\hline $\mathbf{1 5}$ & Commercial Intermediate Goods & 246.7 & 7.2 \\
\hline $\mathbf{1 6}$ & Production Goods & 632.8 & 23.3 \\
\hline
\end{tabular}

As seen in Table-7, five sectors including textile (clothing), mechanical electronics, machinery, commercial intermediate goods and production goods were in the first group before the WTO; After the WTO membership (Table-8), export figures approached the sectors in the second group where final goods were predominant. In five sectors including mines, raw materials, metals, agricultural raw materials and mixed commercial goods in the second group before the WTO (Table-7); After the membership of WTO (Table-8), export figures approached the sectors in the first group where the raw material sector was predominant.

Regardless of the proximity in export figures and the content of the sectors, it is seen that they are in the same group in different sectors. When the changes in export items before and after WTO membership are analysed, it is seen that the least increase in exports is in the agricultural raw materials sector (2 times). Although the WTO membership brings a more liberal order to the Chinese economy, China kept its strategies in line with the interests of the country above the responsibilities brought by the WTO membership. The taxes, prohibitions and quotas on exports were mostly used in restricting agricultural raw material exports in China. For this reason, the sector with the least increase in exports was the agricultural raw materials sector ( 2 times). From this point of view, after the WTO membership, China developed its industry and service sector the most, and the share of agriculture in GDP decreased. Although this change seems to be against the agricultural sector, it actually indicates to economic development (Şimşek 2005: 83). However, we see that the highest increase in exports is in the goods production sector (23 times). When it is examined the change in exports before and after WTO membership, the sectors with the highest increase in exports after the production sector were electrical devices (approximately 20 times) and the machinery sector (19 times). As seen in exports, China, which has a great competitive power in the mechanical-electronic devices and machinery sector, has an important share in the 
world economy in this field. With this development, China has become the number one country in the foreign trade with the USA in the electrical devices and machinery sector.

While most of China's exports consist of medium-level technology and labour-intensive goods with high international competitiveness in foreign trade, capital-intensive goods are among both exported and imported goods. China's exports, $81 \%$ of which are manufactured products, are $19 \%$ basic goods. After its WTO membership, the export sector shows remarkable growth and diversity, compared to other countries. Directing the cheap labour force, which is the biggest advantage in the growth of Chinese foreign trade for goods that require advanced technology, and this made China a sought-after market for developing economies. After China's accession to the WTO (2001-2017), exports of high-tech goods increased by $25 \%$ in the overall export volume, but its share in low-tech goods exports dropped to $50 \%$. In the same period, total exports increased approximately 10 times.

Since 1990, significant changes have occurred in China's export partners as a result of the conclusion of international agreements. With China's WTO membership, the elimination of many trade quotas and restrictions led to the highest level of trade relations with the USA, which has always maintained its place as the leading country in China's exports. While China was the 14th largest USA trading partner in the 1980s, the USA was China's third largest trading partner. The annual foreign trade increase of the two giant economies, which became the biggest trade partners after 2000, reached $20 \%$. The size of the two economies, complementarity factor and mutual interests were effective in the development of US-China trade relations to such extent.

Table 9: Major Countries in China's Export in 2017

\begin{tabular}{|l|c|c|}
\hline Country & Total Exports (Million Dollars) & Total Export Rate (\%) \\
\hline 1. United States of America & 430.328 & $\% 19$ \\
\hline 2. Hong Kong & 279.211 & $\% 12$ \\
\hline 3. Japan & 137.256 & $\% 6$ \\
\hline 4. Korea & 102.704 & $\% 4.5$ \\
\hline 5. Vietnamese & 71.617 & $\% 3.2$ \\
\hline
\end{tabular}

Source: China Exports by Country https//tr.tradingeconomics.com (ET:28.08.2019)

Due to the 2008 crisis with Hong Kong, China's second export partner, exports decreased by $11.4 \%$ in 2009. Apart from this, ChinaHong Kong foreign trade generally showed an upward trend, with a growth of 9.9\% between 2003-2012. Similarly, the rapid development of South Korea over the years in China-Korea foreign trade and the increase in the importance given to mutual trade led to the development of trade relations (Dogru 2016: 88-90).

\section{CONCLUSION}

China, which has managed to become the world's manufacturing centre in foreign trade with its soft power strategy, globalizationoriented balance policy over the last 30 years, has become an economic actor closely followed by the whole world today. As the miracle of Asia, the world's largest manufacturing centre and largest exporter, its journey from the past until the present, by turning its advantages into opportunities in the best way is important in terms of creating an exemplary growth model in the world arena.

China took its position to the highest levels with its WTO membership. WTO membership has brought many benefits in terms of globalization. As it inspired investor countries confidence in attracting foreign investments, there has been an appropriate globalization trend. Its WTO membership also brought to light some issues that could hinder the Chinese economy. China has achieved a steady growth rate of $10 \%$ by transferring labour from sectors with relatively low productivity to those with higher productivity.

In this study, the groupings before and after membership are determined by conducting a cluster analysis on the basis of 25 sectors determined before and after China's WTO membership. The economic relations between the determined groups are investigated. In addition, statistically significant differences are found for each sector before and after WTO membership. This shows that China's membership is meaningful. In the study, after the WTO membership, the agricultural raw materials sector in Chinese exports appeared as the sector with the lowest competitiveness, but the highest competitive power is the production goods, mechanical electronic devices and machinery sector. In other words, after the WTO membership, it is determined that China's total exports increased approximately 10 times during the 2001- 2017 period. 


\section{REFERENCES}

Amighini, A. (2005). China in the International Fragmentation of Production: Evidence from the ICT Industry. The European Journal of Comparative Economics 2(2), 203-219.

Angresano, James W. (2005). China's Development Strategy: A Game of Chess that Countered Orthodox Development Advice. The Journal of SocioEconomics: 471-498.

Becker, J. (2007). Ejder is Raising. NTV Broadcasts: Istanbul. 35.

Bulum, A. Z, Ersöz, F. and Ersöz, T. (2013). A Study on the International Trade Volumes of the World Trade Organization (WTO) Member Countries. Nevşehir Science and Technology Journal. 2 (2), 153-165.

China Country Bulletin, http://www.etonet.org.tr/uploads/cin.pdf ET

Çelik, C. (2016). Increasing the Scope of Turkey's Export Potential Assessment of China's Export Policy. (Master thesis). General Directorate of Economic Models and Strategic Research, Ankara.

Doğru, B. (2016). A Socialist Market Analysis of the Chinese Economy. Academician Bookstore: Ankara.

Ervani, E. Widodo, T. and Purnawan, E.M. (2018). East Asia's Pattern of Export Specialization: Does Indonesia Compete with Japan, China, Hong Kong, Korea and Singapore? Doctoral Program, Faculty of Economics and Business, Universitas Gadjah Mada, Indonesia.

Han, K. and Lee, J. (2012). FDI and Vertical Intra-Industry Trade Between Korea and China. Korea and the World Economy, 13(1), 115-139.

Huang, H. and Wang, S. (2004). Exchange Rate Regimes: China's Experience and Choices, China Economic Review, Elsevier, 15(3), $336-342$.

Jarreau, J. and Poncet, S. (2009). Export Sophistication of China's Export and Foreign Spillovers. Working Papers, CEPII Research Center.

Knight, J. and Song, L. (2005). Towards a Labour Market in China. Oxford University Press. England.

Kösekahyaoğlu, L. and Özdamar, G. (2011). Turkey, China and India a Comparative Study on Sectoral Competitiveness. Journal of Uludağ University Faculty of Economics and Administrative Sciences, 30 (2), 29-49.

Lim, R. (2006). Creating a Globally Connected Asia Community, Finance and Development, 43 (2), 29.

Naughton, B. (2007). The Chinese Economy Transitions and Growth, Cambridge, Massachusetts: The MIT Press, 66.

Öğütçü, M. (1998). Rising Asia. Istanbul: Image Publishing.

Özer, M. and Çiftçi, N. (2009). R\&D Based Endogenous Growth Models and the Impact of R\&D Expenditure on Economic Growth: Panel Data Analysis of OECD Countries. Journal of Social Economic Research, 8(16), 219-240.

Özsoylu, A. F. (2006). China The Awakening of a Giant. Adana: Nobel Bookstore.

Pingyao, L. (2004). China's Foreign Trade: Achievements, Determinants and Future Policy Challenges, China and World Economy, 6, 38-55.

Pingyao, L. (2006). China's Macroeconomics Development: Stages and Nonlinear Convergence, China and World Economy, 14(1), 15-29.

Porath, L.C. (2004). Impacts of China's WTO accession. University Laval Institut Québécois Des Hautes Études Internationales, Quebec. 48.

Shi, L. Sato, H. and Sicular, T. (2008). Rising Inequality in China: Key Issues and Finding, Rising Inequality in China: Challenges to a Harmonious Society, Cambridge University Press, 1-43.

Şahin, D. (2015). Measurement of Competitiveness in Turkey's labor intensive goods: Comparative Analysis with BRIC Countries. Cankiri Karatekin University Journal of the Institute of Social Sciences, 6 (2), 241-262.

Şahin, D. (2017). Foreign Trade of Labor Intensive Goods in Asean-5 Countries Analysis of the structure. Kırıkkale University Journal of Social Sciences, 7 (1), 229- 252.

Tan, Q. (2006). Decollectivisation and Reconstruction of Ownership in Rural China: Some Differences from Central and Eastern European Countries. The University of Liverpool Centre for Central and Eastern European Studies Working Paper, No:52, 6-10.

The Global Trade Atlas (2018), Global Trade Informatıon Services.

The World Bank. https: //data.worldbank.org/indicator/ (E.T: 02.08.2019).

Tseng, W. and Zebregs, H. (2002). Foreign Direct Investment in China: Some Lessons for Other Countries. IMF Policy Discussion Paper, 2(3),1-25. Veeramani, C. (2006). India and China: Changing Patterns of Comparative Advantage? India Development Report. New Delhi: Oxford University Press. 
Wong, J. and Ding, L. (2002). China's Economy into The New Century. Shangai: World Scientific Publishing.

Yang, D. L. (1996). Calamity and Reform in China: State, Rural Society, and Institutional Change Since the Great Leap Famine, Stanford: Stanford University Press.

Zhu, C. J. (2005). Human Resource Management in China: Past, Current, and Future. HR Practices in the Industrial Sector, Routledge Curzon: New York.

https://oec.world/en/profile/country/chn/\#Trade_Balance (ET : 25.07.2019).

https://oec.world/en/profile/country/chn/\#Trade_Balance (ET : 25.07.2019). 